\title{
SILENT SIMULATION: THE ABILITY OF GEOGRAPHY EDUCATION STUDENTS TO DO A HORIZONTAL EVACUATION TO A TSUNAMI SAFE ZONE IN PADANG CITY
}

\author{
Nofrion', Bayu Wijayanto ${ }^{2}$, Rahmanelli ${ }^{3}$, Rery Novio ${ }^{4}$, Surtani ${ }^{5}$, Khairani ${ }^{6}$, \\ Mohammad Zohir Ahmad ${ }^{7}$ \\ 1,2,3,4,5,6Jurusan Geografi, Fakultas Ilmu Sosial, Universitas Negeri Padang \\ Jl. Prof Dr. Hamka, Air Tawar Padang, Sumatera Barat, 25132, Indonesia \\ ${ }^{7}$ School of Education Studies - Universiti Sains Malaysia \\ Penang, 11800, Malaysia \\ e-mail: nofrion@fis.unp.ac.id
}

Received: 14 October 2020, Revised: 05 January 2021, Approvedi: 08 January 2020

\begin{abstract}
This article was written to explain the ability of Geography Education students to do horizontal evacuation to a tsunami safe zone in Padang City and a silent simulation as an alternative of horizontal evacuation. In this research, respondents were asked to do horizontal evacuation in 3 ways, that is walking, power walking and running. The measurement result data were analyzed and compared with the estimated arrival time of tsunami wave in three scenarios based on gender. The results of the research are 1) 47.76 $\%$ of respondents did not know the nearest tsunami safe zone from their places; 2) if the earthquake and tsunami scenarios 1 and 2 occurred, the recommended horizontal evacuation technique was running. Silent simulation is a horizontal evacuation simulation carried out independently by residents without waiting for the simulation schedule by the government or related institutions. Silent simulation can be done alone, with family, or with the closest neighbours and combined with daily activities such as marathons or jogging. Through this silent simulation practice, residents can find out the most appropriate evacuation method and the fastest evacuation route to the nearest tsunami safe zone from their respective homes.
\end{abstract}

Keywords: silent simulation, geography education, tsunami safe zone, Padang

\begin{abstract}
Abstrak
Artikel ini ditulis untuk menjelaskan kemampuan mahasiswa Pendidikan Geografi dalam melakukan evakuasi horizontal ke zona aman tsunami di Kota Padang dan silent simulation sebagai alternatif evakuasi horizontal. Dalam penelitian ini, responden diminta melakukan evakuasi horizontal dengan 3 cara, yaitu jalan kaki, jalan cepat dan lari. Data hasil pengukuran dianalisis dan dibandingkan dengan perkiraan waktu tiba gelombang tsunami pada tiga skenario berdasarkan jenis kelamin. Hasil penelitian adalah 1) $47,76 \%$ responden tidak mengetahui zona aman tsunami terdekat dari tempatnya; 2) jika terjadi gempa bumi dan tsunami skenario 1 dan 2, maka teknik evakuasi horizontal yang direkomendasikan adalah berjalan. silent simulation merupakan simulasi evakuasi horizontal yang dilakukan secara mandiri oleh warga tanpa menunggu jadwal simulasi oleh pemerintah atau instansi terkait. silent simulation bisa dilakukan sendiri, bersama keluarga, atau dengan tetangga terdekat dan dipadukan dengan aktivitas sehari-hari seperti maraton atau jogging. Melalui latihan silent simulation ini, warga dapat mengetahui metode evakuasi yang paling tepat dan jalur evakuasi tercepat menuju zona aman tsunami terdekat dari rumah masing-masing.
\end{abstract}

Kata Kunci: Silent simulation, Pendidikan geografi, Zona aman tsunami, Padang 


\section{INTRODUCTION}

Padang City is one of $60 \%$ of cities in Indonesia that has the potential to be hit by an earthquake and tsunami. It is stated in the document of the Contingency Plan for Tsunami of Padang City (2012) that Padang City from the probability aspect gets the number of 4 which means that $60-80 \%$ of the potential for a disaster is likely to occur. If the potential disaster occurs, the impact will be at level 5 or $80-90 \%$ of the area in the red zone will be destroyed and completely paralyzed including Air Tawar, North Padang Sub District where the UNP campus is located (Anisya \& Swara, 2017). LIPI researcher, Dany Hilman, revealed that the potential for earthquakes and tsunamis in the megathrust reaches 8.8 on the Richter scale. The magnitude of the potential for the earthquake is not much different from Sieh's estimate of 8.9 on the Richter scale (Stein \& Okal, 2007; McCloskey dkk, 2008; Pemerintah Kota Padang, 2012; BPBD Kota Padang, 2020).

The results of LIPI's research which were published in www.gitews.org and reported through the media Jawapos on January 25, 2019, illustrated that the potential for an earthquake and tsunami could occur and Padang was one of the seven districts/cities affected in West Sumatra. Geographically, about $60 \%$ of the area of Padang City is in the red zone. About five hundred thousand people are under the threat of a tsunami which is estimated to reach an altitude of $6-10 \mathrm{~m}$ on the shoreline.

Based on this data, Padang City residents who are in the Red Zone must always improve their preparedness for the potential for earthquakes and tsunamis. The government is responsible for improving the preparedness of residents against the threat of disasters to reduce the number of people affected by disasters. Based on the Committee on Disaster Research in The Social Sciences/CDRSS (2006), explained that the disaster risk reduction framework includes three important processes, i.e., 1) hazard mitigation (structural and nonstructural mitigation), 2) disaster preparedness (building community preparedness for disaster risk), 3) emergency response (issue of disaster prediction and warning dissemination, evacuation, mobilization and emergency organization, volunteering, search and rescue, damage control and restoration).

Natural disasters such as earthquakes and tsunamis and man-made disasters both have the potential to threaten human life and property and damage the environment, especially for people who live in disaster-prone areas. In Padang City specifically, with the three existing scenarios, it is estimated that some residents do not have time to save themselves when the tsunami comes (Imamura et al., 2012). Building self, family, and communitypreparedness is an absolute thing that must be done sustainably. Building disaster preparedness is a disaster management effort. This effort is carried out proactively before the disaster strikes by involving the surrounding community (Raja, Hendarmawan \& Sunardi, 2017).

So far, the government has often simulated earthquakes and tsunamis by involving educational units such as schools and campuses. However, this simulation is more focused on vertical evacuation to the available buildings or shelters, including the campus of Universitas Negeri Padang and its surroundings. Meanwhile, horizontal simulations are rarely done.

Based on the analysis of the potential for earthquakes and tsunamis as well as the strength of the earthquake and the arrival time of the tsunami in Padang, it is necessary to carry out simulations in the form of horizontal evacuation, especially for students of Universitas Negeri Padang (UNP) and the surrounding community. In the context of this research, it is estimated that the impact of the earthquake caused 80 - $90 \%$ of buildings and other infrastructure in the red zone to be destroyed and paralyzed. So, there is no other choice for residents who survived the earthquake to immediately move away from the coast by doing horizontal evacuations to the tsunami safe zone on DPR Street, Tunggul Hitam. 
This point is located $4.1 \mathrm{~km}$ from the main campus of Universitas Negeri Padang at Air Tawar. Since the distance between the shoreline and the nearest tsunami safe zone point is quite far, it is necessary to practice or simulate an earthquake and tsunami, especially for doing horizontal evacuation. According to Yamazaki et al., (2010) evacuation simulation is very beneficial for the community and simultaneous simulation is the right strategy to increase preparedness so that victims can be minimized.

According to Chu et al., (2019), simulations help reduce panic among residents because they already know where to run to the evacuation location or shelter. The simulation also provides the direction of the travel path that must be passed to the safe zone (Mustafa, 2009). Syukri and Mukhlis' research (2016) reveals that simulations are useful for providing knowledge to residents about the correct direction of evacuation. Shaw et al., (2004) state that evacuation practice will provide the best choice for the community to save themselves. Based on this rationality, the researcher conducted simple research by involving students of Geography Education, Faculty of Social Sciences, Universitas Negeri Padang who live or rent a room around campus or near the beach. This research aims to determine the ability of students to do horizontal evacuation by walking, power walking and running. The results of the time records achieved are then compared with the estimated arrival time of the tsunami wave at the coast of Padang City. The results of this research are expected to be the basis for students and the community to choose the right evacuation method and a fast evacuation route to arrive at a tsunami safe zone. In this ressearch it is called "Silent Simulation".

\section{METHOD}

This article is the result of quantitative descriptive research through simulation activities carried out in September - October 2019. The population of this research was students of the
Geography education study program of 2016, 2017, 2018, and 2019 with a total of 517 people. The sample is determined by considering, 1) students who live near the beach or around the campus of Universitas Negeri Padang, 2) students who want to participate in this research voluntarily and 3) students who do not have a history of congenital diseases and 4) students who have received permission from their parents. Based on these criteria and considerations, the number of samples is 67 people.

In this research, all respondents were asked to do a horizontal evacuation starting from the building B of Faculty of Social Sciences UNP and finish at a tsunami safe zone on DPR Street, Tunggul Hitam, which is about $4.1 \mathrm{~km}$ away. Each respondent did horizontal evacuations three times in three ways, i.e walking, power walking and running. An overview of the research flow as shown in the following figure:

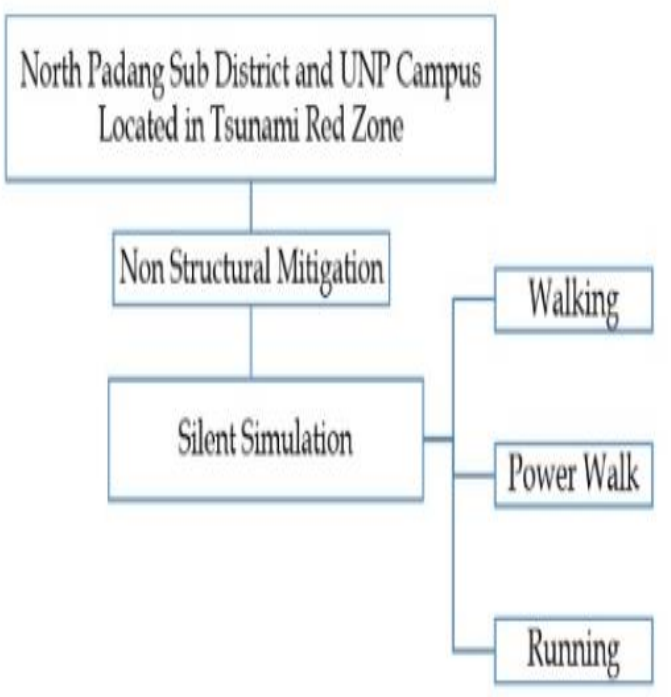

Figure: 1. Research Framework

The tools used in this research are smart running applications, stopwatch and Google maps. The results of the time records achieved by respondents in the three methods carried out were then compared with the estimated arrival time of the tsunami wave in Padang City which included three scenarios, that is: 
Table 1. Scenarios of Earthquake Strength and Estimated Arrival Time of Tsunami in Padang City

\begin{tabular}{cccc}
\hline Scenarios & $\begin{array}{c}\text { Potential for } \\
\text { Earthquake } \\
\text { Strength (SR) }\end{array}$ & $\begin{array}{c}\text { Estimated } \\
\text { Arrival Time of Mileage } \\
\text { Tsunami } \\
\text { (Minutes) }\end{array}$ & \\
\hline 1 & 8,5 & 33,157 & 2,647 \\
2 & 8,75 & 32,915 & 2,264 \\
3 & 9,0 & 17,098 & 1,365 \\
\hline
\end{tabular}

Source: Firmana (2012)

The tools and materials used in this research were the GPS Essential app for Android, a stopwatch/clock, a pen and a notebook, and a GIS to create maps of research locations and horizontal evacuation routes. The results of the respondents' time achievements will be compared with the estimated arrival time of tsunami wave in Padang City and described descriptively.

\section{RESULT}

Research to determine the ability of Geography Education students to do horizontal evacuations from the campus of Universitas Negeri Padang (about 800 meters from the shoreline) to the nearest tsunami safe zone on DPR Street, Tunggul Hitam (a distance of $4.1 \mathrm{~km}$ ) was done in 3 phases:

\section{A phase of Socialization and explanation of evacuation routes and techniques to be carried out}

This phase was done twice in the classroom on July $6^{\text {th }}$ and $13^{\text {th }} 2019$. The researcher explained to the respondents about the purpose of the research, the route to be taken and the three types of horizontal evacuation techniques to be implemented. The route to be taken starts from Building B of Faculty of Social Sciences UNP - The rear exit of Building B, Prof. Hamka street - a crossroad of Tunggul Hitam - DPR Street of Dadok Tunggul Hitam - Tsunami Safe Zone. As shown in the map of Figure 2 below:

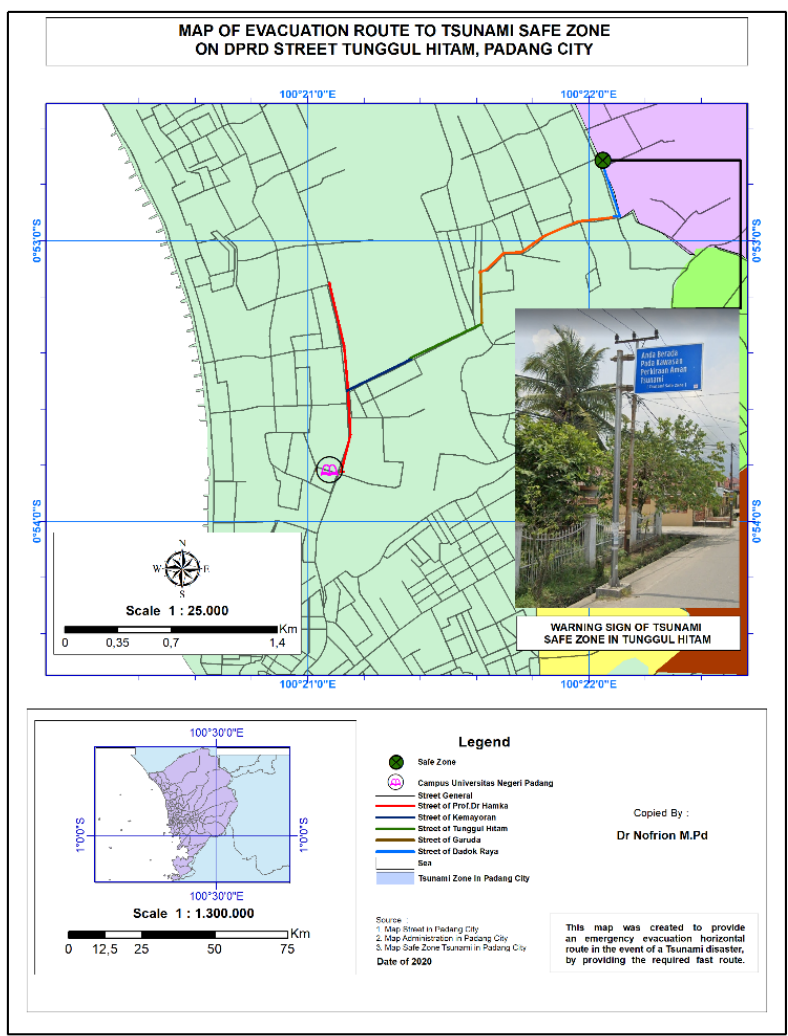

Figure 2. Horizontal Evacuation Simulation Route Map 
In the early part of this phase, a test of the respondent's knowledge of the route to be taken was conducted. The results were surprising. As shown in the following Figure 2 below:

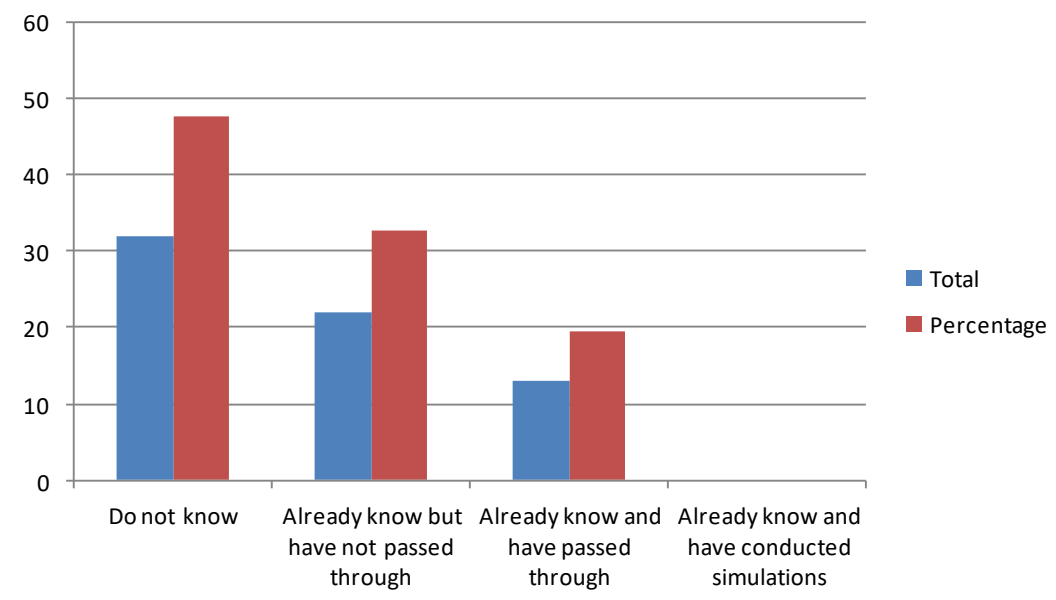

Figure 3. Respondents' Initial Knowledge of the Evacuation Simulation Routes

This preliminary data shows that almost half of the respondents do not know yet the tsunami safe zone they must reach if an earthquake and tsunami happens that requires residents on the coast to do a horizontal evacuation. As part of the residents who live near Air Tawar beach, Padang City and are in the tsunami red zone, students who are respondents in this research should know the closest tsunami safe zone. This ignorance is very dangerous and can threaten the safety of their lives if one day a disaster occurs. This condition is one of the bases for the need to conduct socialization and simulation of horizontal evacuation regularly. There must be a sign or directions to a tsunami safe zone on the beach and along the evacuation route.

\section{Horizontal Evacuation Simulation with Walking Technique}

The first Horizontal Evacuation Simulation was conducted on July 21st, 2019 using walking technique. The 67 in total simulation participants simulate horizontal evacuation using this walking technique starting from the starting point of Building B Faculty of Social Sciences UNP and finish at the tsunami safe zone on DPR Street, Tunggul Hitam with a distance of $4.1 \mathrm{~km}$. The following is the average travel time based on gender.

Table 2. Average Travel Time Based on Gender

\begin{tabular}{lcc}
\hline \multicolumn{1}{c}{ Gender } & Quantity & $\begin{array}{c}\text { Average Travel } \\
\text { Time (minutes) }\end{array}$ \\
\hline Male & 17 & 42,94 \\
Female & 50 & 53,12 \\
\hline
\end{tabular}

Source: Research Data of Nofrion (2020)

If the average travel time using the walking technique is compared with the estimated arrival time of tsunami wave using three scenarios, the result is:

Table 3. Comparison of Average Travel Time with Estimated Arrival Time of Tsunami in Padang City

\begin{tabular}{|c|c|c|c|}
\hline $\begin{array}{l}\text { Scenarios of Earthquake and } \\
\text { Tsunami in Padang }\end{array}$ & $\begin{array}{l}\text { Estimated Arrival Time of } \\
\text { Tsunami Wave (minutes) }\end{array}$ & $\begin{array}{l}\text { Average Travel } \\
\text { Time (minutes) }\end{array}$ & Information \\
\hline $1(8,5 \mathrm{SR})$ & 33,157 & $\begin{array}{l}\text { Male }=42,94 \\
\text { Female }=53,12\end{array}$ & $\begin{array}{l}\text { Not achieved } \\
\text { Not achieved }\end{array}$ \\
\hline $2(8,9 \mathrm{SR})$ & 32,915 & $\begin{array}{l}\text { Male }=42,94 \\
\text { Female }=53,12\end{array}$ & $\begin{array}{l}\text { Not achieved } \\
\text { Not achieved }\end{array}$ \\
\hline 3 (9,0 SR) & 17,098 & $\begin{array}{l}\text { Male }=42,94 \\
\text { Female }=53,12\end{array}$ & $\begin{array}{l}\text { Not achieved } \\
\text { Not achieved }\end{array}$ \\
\hline
\end{tabular}

Source: Firmana (2012); Nofrion (2020) 


\section{Horizontal Evacuation Simulation with Power Walking Technique}

Horizontal evacuation simulation using power walking technique was done on July 28th, 2019. This horizontal evacuation simulation was carried out by 67 respondents consisting of 17 men and 50 women. The average travel time for male is 31,53 minutes and the average travel time for female is 39,30 minutes. As shown in the table 4 ;
Table 4. Average Travel Time Based on Gender

\begin{tabular}{lc}
\hline Gender & $\begin{array}{c}\text { Average Travel Time } \\
\text { (minutes) }\end{array}$ \\
\hline Male & 31,53 \\
Female & 39,30 \\
\hline
\end{tabular}

Furthermore, the data on the average travel time of the respondents were compared with the estimated arrival time of the tsunami wave in the three earthquake and tsunami scenarios in Padang City. The results are in Table 5 below:

Table 5. Comparison of Average Travel Time with Estimated Arrival Time of Tsunami in Padang City

\begin{tabular}{cclc}
\hline $\begin{array}{c}\text { Scenarios of Earthquake } \\
\text { and Tsunami in Padang }\end{array}$ & $\begin{array}{c}\text { Estimated Arrival Time of } \\
\text { Tsunami Wave (minutes) }\end{array}$ & $\begin{array}{c}\text { Average Travel } \\
\text { Time (minutes) }\end{array}$ & Information \\
\hline $1(8,5 \mathrm{SR})$ & 33,157 & $\begin{array}{l}\text { Male }=31,53 \\
\text { Female }=39,30\end{array}$ & $\begin{array}{c}\text { Achieved } \\
\text { Not achieved } \\
\text { Achieved } \\
\text { Not achieved }\end{array}$ \\
$2(8,9 \mathrm{SR})$ & 32,915 & $\begin{array}{l}\text { Male }=31,53 \\
\text { Female }=39,30\end{array}$ & $\begin{array}{c}\text { Male }=31,53 \\
\text { Not achieved } \\
\text { Fet achieved }\end{array}$ \\
\hline
\end{tabular}

Source: Firmana (2012); Nofrion (2020)

The average travel time for male respondents was 31.53, which means that they were able to pass the estimated arrival time of tsunami wave in Padang City in scenarios 1 and 2. Meanwhile, female respondents had not been able to pass the estimated arrival time of the tsunami. With this condition, it can be estimated that female residents will be swept away by the tsunami on their way to the tsunami safe zone even though they have done the power walking technique.

\section{Horizontal Evacuation Simulation with Running Technique}

The horizontal evacuation simulation using running technique was done on

Table 7. Comparison of Average Travel Time with Estimated Arrival Time of Tsunami in Padang City

\begin{tabular}{cclc}
\hline $\begin{array}{c}\text { Scenarios of Earthquake } \\
\text { and Tsunami in Padang }\end{array}$ & $\begin{array}{c}\text { Estimated Arrival Time of } \\
\text { Tsunami Wave (minute) }\end{array}$ & $\begin{array}{c}\text { Average Travel Time } \\
\text { (minutes) }\end{array}$ & Information \\
\hline $1(8,5 \mathrm{SR})$ & 33,157 & Male $=22,06$ & Achieved \\
$2(8,9 \mathrm{SR})$ & 32,915 & Female $=30,92$ & Achieved \\
Male $=22,06$ & Achieved
\end{tabular}

August $4^{\text {th }}, 2019$. The average travel time for male and female respondents is:

Table 6. Average Travel Time Based on Gender

\begin{tabular}{lc}
\hline Gender & Average Travel Time (minutes) \\
\hline Male & 22,06 \\
Female & 30,92 \\
\hline
\end{tabular}

Source: Research Data of Nofrion (2020)

Furthermore, the data on the average travel time of the respondents were compared with the estimated arrival time of the tsunami wave in the three earthquake and tsunami scenarios in Padang City. The results are in Table 7 below: 
Based on the data in Table 7, it can be seen that the average travel time for male and female respondents to the tsunami safe zone with running technique is shorter than the estimated arrival time of tsunami wave in scenario 1 and 2 . Thus, it can be estimated that the residents who do horizontal evacuation with the running technique have arrived at a tsunami safe zone before the tsunami wave arrives due to an earthquake with a magnitude of 8.5 and 8.9 on the Richter scale or earthquake scenario 1 and 2. However, the average travel time of respondents has not been able to reach the estimated arrival time of the tsunami wave in scenario 3 or the estimated earthquake magnitude of 9.0 on the Richter scale. Based on a comparison between the average travel time of male and female respondents with the estimated arrival time of tsunami wave in Padang City shows:

1. Male and female respondents will be swept away by the tsunami wave if they do a horizontal evacuation using the walking technique in all earthquake and tsunami scenarios.

2. Male respondents can reach a tsunami safe zone by using power walking technique in earthquake and tsunami scenarios 1 and 2 only. However, female respondents were not able to get to a tsunami safe zone using power walking technique in all scenarios.

3. Male and female respondents were able to reach a tsunami safe zone before the tsunami wave reached Padang City in scenarios 1 and 2 if they carried out a horizontal evacuation using the running technique. However, both of them will be swept away by a tsunami wave if an earthquake and tsunami scenario $3(9.0$ on the Richter scale) occur even though they have used running technique.

The horizontal evacuation simulation results show that the residents of Padang City who live near Air Tawar beach and its surroundings must master the tsunami evacuation route and be trained to do horizontal evacuation by using power walking and running technique. This simulation is done by following the existing evacuation routes. However, some shortcuts can be chosen by the residents so that the travel time records are shorter than the estimated arrival time of the tsunami wave. It can be done if the residents are accustomed to going through the main evacuation route while looking for other routes as a shortcut. This is by the publication of Safrina (2015) which states that determining the shortest path and paying attention to alternative routes that can be traversed with the shortest distance is the fastest path to the assembly point. Residents also need to know the location of the assembly point in the tsunami safe zone (Trisakti et al., 2007) so that they do not panic when a disaster occurs (Mustafa, 2009).

Therefore, the evacuation simulation must be carried out sustainably. However, it seems that there is not enough response from the community for simulations of the earthquake and tsunami disasters carried out massively by the government. This is due to the awareness and simulation time that is not suitable for the residents' free time. Some residents were working at the time of the simulation so they preferred to work instead of participating in the earthquake and tsunami simulations.

One alternative effort that can be done is to carry out a "silent simulation". The meaning of "silent simulation" is an independent simulation carried out by a person or a family according to their respective agreements. The implementation of the "silent stimulation" can be integrated with the sports agenda of family, jogging, marathon, etc. The difference is that "silent simulation" is an activity of power walking or running from the starting point of each 
residence to the nearest tsunami safe zone. If this is repeated, it will help residents to master the evacuation route, know the closest evacuation route and choose the right evacuation technique when a disaster occurs (UN-ISDR, 2010).

If the horizontal evacuation simulation using the "silent stimulation" technique is carried out continuously, it will encourage community preparedness to face various potential disasters in the future (Permana, 2007). Disaster preparedness, especially tsunami, really needs to be done because the tsunami caused damage to the property and a lot of death (Ruwanpura et al., 2009). This Silent Simulation will be part of a comprehensive approach to reducing the impact of disasters. Silent Simulation is a way to live in harmony and friendly with the threat of disasters by increasing community preparedness by actively involving the community. This step is a form of disaster management philosophy (Maarif, 2012).

Silent simulation is very beneficial for the community because it is self and family - based as well as own decisions. Each individual or family can choose the best type and evacuation technique according to their respective conditions and the time to do so. Silent simulation in the form of a horizontal evacuation simulation to a tsunami safe zone will help the community to achieve the best travel time by referring to the estimated arrival time of the tsunami wave (Syukri and Mukhlis, 2016); (LIPI-UNESCO/ISDR, 2006).

In the silent simulation, the community can choose the evacuation technique, whether by walking, power walking or running. The simulation results show that running is the most recommended technique because it is based on data of human walking and running speed during the disaster, estimated at 0.97 - 1.07 meters/second (Sugimoto, 2003 in SDC-R-70022, 2007). Silent simulations must be carried out sustainably by individuals and families because there is no technology capable of determining the exact time of arrival and occurrence of earthquakes and tsunamis until now. Preparing before a disaster strike is one of the characteristics of a disaster preparedness community that must be continuously socialized and trained. Therefore, individual and familybased programs such as the "silent simulation" are useful for developing tsunami-resilient communities through awareness and education as well as continuous training/ simulations. The large population of Padang City and the real threat of disaster require government attention to plan disaster-prepared community development (Dian \& Manurung, 2010). The Silent Simulation is a horizontal evacuation technique that can be used as an option to improve community preparedness.

\section{CONCLUSION}

Based on the earthquake and tsunami scenario in Padang city, the people living near Air Tawar Padang beach, including students, must carry out regular horizontal evacuation simulations. The simulation activity does not have to wait for the formal simulation schedule carried out by the government. Communities can do this on their initiative which is integrated with personal and family activities such as sports and other activities. By conducting a silent simulation, the community can choose the fastest evacuation route, the right horizontal evacuation technique, and prepare the community physically and psychologically for potential disasters that will occur in the future.

\section{REFERENCES}

Anisya, A., \& Swara, G. Y. (2017). Aplikasi Pencarian Shelter Tsunami Terdekat di Kota Padang Menggunakan Metode Best First Search. Jurnal Teknoif, 5(1).

BPBD Kota Padang. (2020). Kondisi Kebencanaan Kota Padang dan Kebutuhan Early Warning System (EWS). Disampaikan oleh Kepala Pelaksana BPBD Kota Padang Drs. Barlius, MM di Padang tanggal 30 September 2020. 
Chu, H., Yu, J., Wen, J., Yi, M., \& Chen, Y. (2019). Emergency evacuation simulation and management optimization in urban residential communities. Sustainability, 11(3), 795.

Disasters, F. H. (2006). Understanding Human Dimensions. Committeeon Disaster, Research in the Social Sciences National Research Council.

Firmana, A. (2012). Perhitungan Iklim Gelombang di Perairan Kecamatan Muara Gembong, Kabupaten Bekasi, dari Data Angin Selama 25 Tahun (1984-2008). Tugas Akhir. Teknik Geodesi dan Geomatika. Institut Teknologi Bandung

Imamura, F., Muhari, A., Mas, E., Pradono, M. H., Post, J., \& Sugimoto, M. (2012). Tsunami disaster mitigation by integrating comprehensive countermeasures in Padang City, Indonesia. Journal of Disaster Research, 7(1), 48-64.

LIPI, T. (2006). Kajian Kesiapsiagaan Masyarakat dalam Mengantisipasi Bencana Gempa dan Tsunami di Indonesia. Bandung: LIPI.

Maarif, S. (2012). Merapi menyapa kehidupan hidup harmonis di Lereng Merapi. Jakarta: Badan Nasional Penanggulangan Bencana.

McCloskey, J., Antonioli, A., Piatanesi, A., Sieh, K., Steacy, S., Nalbant, S., ... \& Dunlop, P. (2008). Tsunami threat in the Indian Ocean from a future megathrust earthquake west of Sumatra. Earth and Planetary Science Letters, 265(1-2), 61-81.

Mustafa, B. (2009). Peran Puslit Geoteknologi dalam Optimalisasi Pemanfaatan Sumber Daya Alam dan Mitigasi Kebencanaan di Indonesia. Prosiding Pemaparan Hasil Penelitian Puslit Geoteknologi - LIPI Bandung, 3 Desember 2009. ISBN: 978-979-863616-5.

Oktiari, D., \& Manurung, S. (2010). Model Geospasial Potensi Kerentanan Tsunami Kota Padang. Jurnal Meteorologi dan Geofisika, 11(2).
Pemerintah Kota Padang. (2012). Rencana Kontinjensi Menghadapi Tsunami Kota Padang.

Permana, H., Carolita, I., \& Rasyid, M. (2007). Pedoman Pembuatan Peta Jalur Evakuasi Bencana Tsunami. Jakarta: Kementerian Negara Riset dan Teknologi.

Raja, Z. D. G., Hendarmawan, H., \& Sunardi, S. (2017). Kajian Upaya Pengurangan Risiko dan Kesiapsiagaan Masyarakat Terhadap Ancaman Bencana Tanah Longsor (Desa Ndito Kecamatan Detusoko Kabupaten Ende Provinsi Nusa Tenggara Timur). Jurnal Lingkungan dan Bencana Geologi, 8(2).

Ruwanpura, J., Wickaramaratne, S., Braun, A., \& Wirasinghe, S. C. (2009). Planning and modelling for mitigation of tsunami impacts. Civil Engineering and Environmental Systems, 26(2), 195-209.

Safrina, L., Hermansyah, H., \& Aulia, T. B. (2015). Evaluasi Titik Evakuasi Gempa Bumi dan Tsunami Pada Badan Layanan Umum Daerah Rumah Sakit Jiwa Aceh. Idea Nursing Journal, 6(2), 43-52.

SDC-R-70022. (2007). Pedoman Perencanaan Pengungsian Tsunami (Tsunami Refuge Planning). Aceh: SDC-R-70022.

Shaw, R., Kobayashi, K. S. H., \& Kobayashi, M. (2004). Linking experience, education, perception and earthquake preparedness. Disaster Prevention and Management: An International Journal.

Stein, S., \& Okal, E. A. (2007). Ultralong period seismic study of the December 2004 Indian Ocean earthquake and implications for regional tectonics and the subduction process. Bulletin of the Seismological Society of America, 97(1A), S279-S295.

Syukri, A. (2015). Studi Jalur Evakuasi Tsunami Horizontal di Kabupaten Padang Pariaman. Jurnal Ilmiah Rekayasa Sipil, 13(2), 1-12.

Trisakti, B., Carolita, I., \& Nur, M. (2010). Simulasi Jalur Evakuasi Untuk 
Bencana Tsunami Berbasis Data Penginderaan Jauh (Studi Kasus; Kota Padang, Propinsi Sumatera Barat). Jurnal Penginderaan Jauh dan Pengolahan Data Citra Digital, 4(1).

Moench, M., Ahmed, S., Mustafa, D., Khan, F., Reinhard, M., Daniel, K., ... \& Pharoah, R. (2016). Protecting Development Gains: Reducing Disaster Vulnerability and Building Resilience in Asia and the Pacific. Statistics (NY), 2010(17), 20032009.

Yamazaki, F., Zavala, C., Nakai, S., Koshimura, S. I., Saito, T., \& Midorikawa, S. (2010, March). Enhancement of earthquake and tsunami disaster mitigation technology in Peru: A SATREPS project. In Proceedings of the 7 th International Conference on Urban Earthquake Engineering (pp. 15011506).

www.gitews.org 